\title{
Report on Some Socio-Religious Importance Plants in Village Ghunghuti District Umaria, Madhya Pradesh, Central India
}

\author{
Ramesh Kumar Ahirwar ${ }^{1}$, Ganesh Singh Sandya ${ }^{2}$ \\ ${ }^{1}$ Department of Botany, Govt. Nehru P.G. College Burhar, District Shahdol, Madhya Pradesh - 484110 (India) \\ ${ }^{2}$ Department of Botany, Pt. S. N. S. Govt. P. G. (Autonomous) College Shahdol - 484001 (India)
}

\begin{abstract}
The present survey deals about the information regarding the socio-religious importance of plants in village Ghunghuti district Umaria Madhya Pradesh region of Central India. The rural and forest area of Madhya Pradesh were surveyed and covered extensively to record the socio-religious plants. During the survey 51 plant species of angiosperms have been enumerated which are being used by the people in various social and religious customs like marriage, worshiping, child birth and festivals.
\end{abstract}

Keywords: Socio-religious plants, Tribes, Worship, Madhya Pradesh

\section{Introduction}

Ghunghuti village is present in district Umaria. This forest is very dense forest. District Umaria is located to the North East of Madhya Pradesh. Mathematically the coordinates of the District extend from $23038^{\prime}$ to $24020^{\prime}$ North and $80028^{\prime}$ to $82012^{\prime}$ East. It has geographical area of $4548 \mathrm{sq} . \mathrm{km}$. The greatest length of the district is about $150 \mathrm{~km}$. from north to south and the greatest width is about $60 \mathrm{~km}$ from east to west. The population of the district on the basis of 2001 census is 515963 . Out of which about $83 \%$ population resides in rural areas. The district has extensive forests. About $42 \%$ of the total area is covered by forests only. The District is rich in minerals. The most important mineral found in the district is coal and as a result 8 mines are being operated by South Eastern Coalfield Limited in the district. The famous Bandhavgarh National Park (Tala) and Sanjay Gandhi Thermal Power Station Mangthar (Pali) are located in the district. Umaria was formerly the headquarters of the South Rewa District and thereafter the headquarters town of the Bandhavgarh tehsil. It is situated at a distance of about $69 \mathrm{Km}$. from Shahdol, the parent district. Metalled roads connect the town with Katni, RewaShahdol.

Umaria is also a railway station on the Katni-Bilaspur section of the South-Eastern Railway. Bandhavgarh is the name of tehsil in Umaria District. Formerly it was the capital of the Bandhavgarh Kingdom of the Magha dynasty, then the head-quarters of the tehsil. At present its headquarters is Umaria. The fort of Bandhavgarh is a place of considerable archaeological and historical importance. It is a natural impregnable fort and stands on a hill, at an attitude of about 2430 metres above sea-level. The Bamnia hill is also a part of the fort, because it is enclosed by a rampart. The fort is on the Rewa-Umaria road, at a distance of about $41 \mathrm{Km}$ from Umaria Town. Chandia is situated on the Umaria-Katni road, at a distance of about $21 \mathrm{~km}$. from Umaria. The railway station of ChandiaKhas, known as Chandia railway station. The most important spot of ChandiaKhas is a small temple, enshrining Goddess Kalika. Her mouth is wide open, but her out-stretched tongue is broken. There is also a old temple of god Rama and his consort Janaki. It was the seat of Thakur of Chandia. A small fair meets at SuraswahiChandia for 3 days in February/March, on the occasion of Shivaratri. PaliBirsinghpur is situated on the Umaria-Shahdol road, at a distnace of about $36 \mathrm{~km}$. from Umaria. Another road goes from Pali to Mandla via Dindori. Pali is also a railway station, and there is a rest house for the tourists to stay. The Station is known as the Pali-Birsinghpur station. Near the railway station there is a temple, enshrining Birasinidevi. By popular belief she is Goddess Kali, represented here as skeleton Goddess, but with her mouth closed. Many remains of old jain idols kept here in some Hindu temples. The annual fairs are held both in October and March, on the occasion of Navaratri, near the temple of Goddess. Umaria Town The headquarters town of the Umaria district and Bandhavgarh tehsil, formerly umaria was the headquarters of the South Rewa District. It is situated at a distance of about $69 \mathrm{~km}$ from Shahdol. Near the railway station stands a Siva temple, known as the Sagara temple. It was an old shrine, recently remodeled. Its main gates are still intact with beautiful stone statues, carved in Khajuraho models. Near about is Jwalamukhi temple. About $6.5 \mathrm{~km}$ away from the town, there is another temple, with similar carvings of the Khajuraho pattern. It is known as the Mariwal temple.

Umaria is famous for its coal-mines, which were opened in 1881 by the Government of India and transferred to the RewaDarbar in the same year, mainly to meet the requirement of railway at Katni. The toppgraphy is divisible into plains, mountains and plateau. Plateau occupies the middle part of the district. This is called plateau of Baghelkhand. Maikal range constitutes southern part of the

\section{Volume 4 Issue 12, December 2015}




\section{International Journal of Science and Research (IJSR) \\ ISSN (Online): 2319-7064 \\ Index Copernicus Value (2013): 6.14 | Impact Factor (2014): 5.611}

district. The hilly tracts of Central India are covered by luxuriant vegetation. The tribals are distributed mostly in the aforesaid hilly tracts of the thick forest. They are adopted to live in these habitations. Baiga tribes are the dominant tribe's inhabitating in Umaria district and most of the tribal populations are using plants for their domestic livestock. The Eihnobotany and Ethnoveterinary plants and traditional knowledge of ethno medicines are gradually depleting due to lack of proper records and documentation. They usually collect their materials from nearly forests and use in their health care system, which is well developed and proven successfully for generation together (Figure 1-2).

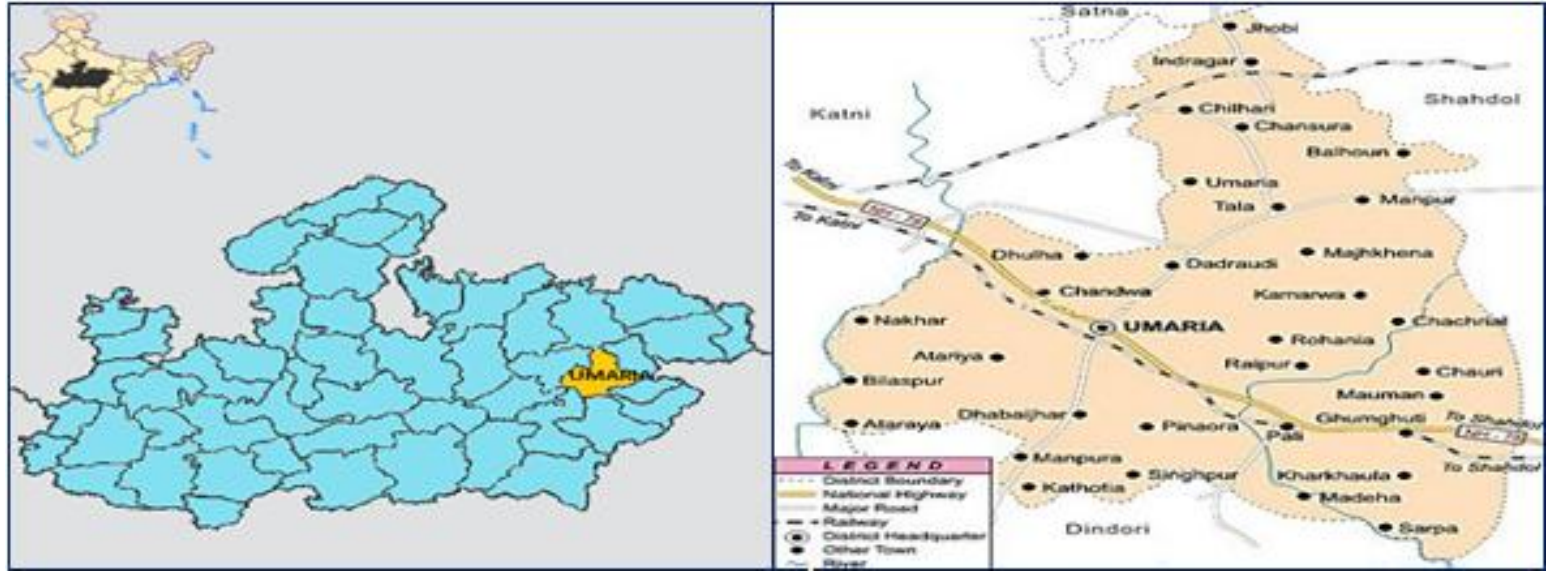

Figure 1: Showing of District Umaria and study site village Ghunghuti, in Madhya Pradesh, India

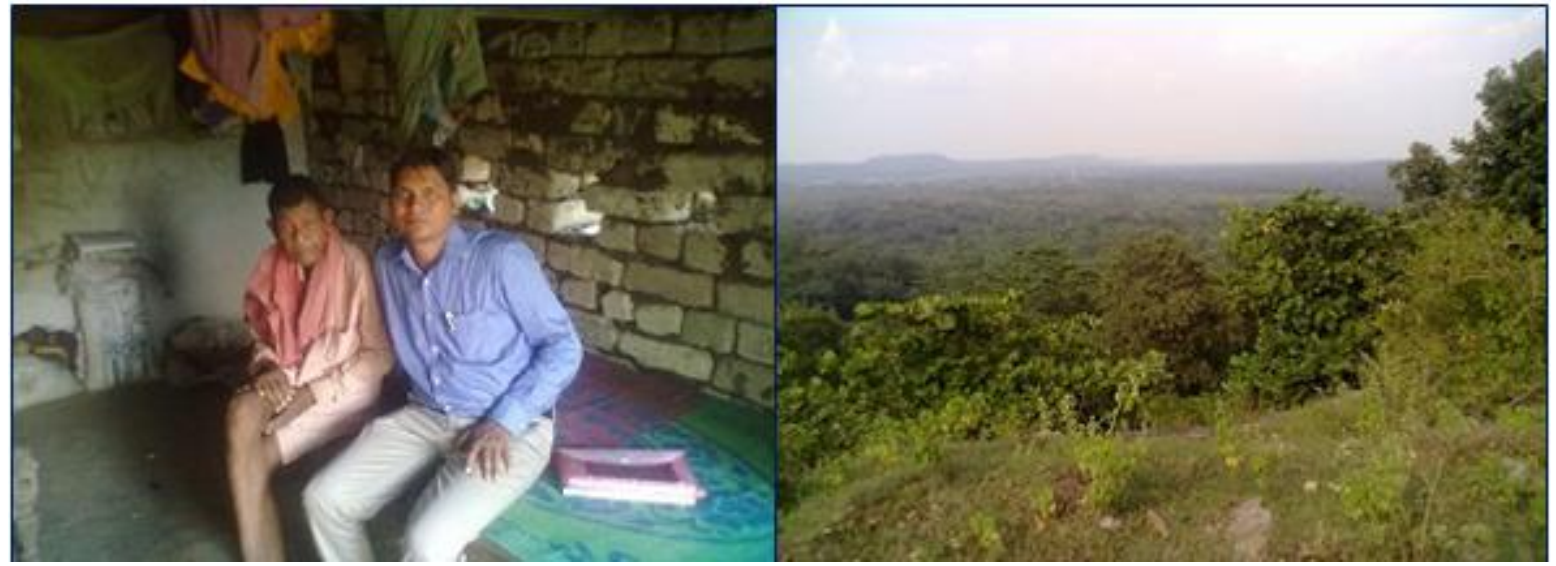

Figure 2: Showing on healer Mr. Bhola Bhumia and Dr. Ramesh Kumar Ahirwar interviews at village Ghunghuti and forest area

\section{Material and Method}

During the current January 2015 to September 2015 the different area of district Umaria village Ghunghuti were surveyed and covered extensively to record the socioreligious role of plants. The information collected on the basis of intensive interviews and long discussions with villagers of Madhya Pradesh region regarding the uses of plants in different rites and rituals11. All of the plants were recorded and identified by consulting the available literatures. A list of plants is alphabetically prepared along with their botanical name, local name, family and uses. Some of the noteworthy contributors are those of Ahirwar (2010, 2011, 2015), Ahirwar (2013), Brijlal and Dube (1992), Gupta et al. (1999) Gupta and Mishra (2000), Jain (1965), Jain et al. (1976), Khan et al. (2008), Khanna et al. (2004), Kumar and Sikarwar (2002), Maheshwari (1990), Oommachan. andMasih. (1993), Oommachanet al. (1986), Sahu (1983) and Vermaet al. (1995).

\section{Results and Discussion}

Present survey we can find 51 plant species belonging to different families of monocot and dicot of Angiosperms have been enumerated and recorded in Madhya Pradesh region at village Ghunghuti, which are being used in different social and religious customs. The relevant information regarding the role of socio-religious plants have been documented (Table 1).

\section{Conclusion}

During this survey on the basis of foregoing discussion it can be concluded that the 51 plant species have been enumerated which are being used in different rites and rituals like marriage ceremony, worshiping, child birth, festivals and cremation by the people of Madhya Pradesh region. People treat these plants like socio-religious entity and worship them. Their devotion to these plants is so high that they never think to cut these plants. If it happens so they try to expiation. It is hoped that the present study may be 


\section{International Journal of Science and Research (IJSR) \\ ISSN (Online): 2319-7064 \\ Index Copernicus Value (2013): 6.14 | Impact Factor (2014): 5.611}

useful to mankind. It will inspire to conserve these plant species wherever possible. valuable information's to Socio-religious plants and their uses various ceremony.

\section{Acknowledgement}

We thankful to the tribal and rural people of district Umaria village Ghunghuti of Madhya Pradesh for providing

Table 1: Some Socio-religious plants used by tribes in village Ghunghuti, district Umaria, Madhya Pradesh

\begin{tabular}{|c|c|c|c|c|c|}
\hline S. No. & Scientific name & Local name & Family & Uses of plant parts & $\begin{array}{l}\text { Socio-religious uses of } \\
\text { Ceremony }\end{array}$ \\
\hline 1 & Aegle marmelos & Bel & Rutaceae & Leaves & Mahashivaratri \\
\hline 2 & Azadirachta indica & Neem & Meliaceae & Leaves & Bad effect of Soul \\
\hline 3 & Abrus precatorius & Ghumchi. & Papilionaceae & Fruits & Marriage Ceremony \\
\hline 4 & Anthocephalus indicus & Kadam & Rubiaceae & Whole plant & Lord Krishna \\
\hline 5 & Bambusa bambos & Bans & Poaceae & Stem & Marriage Ceremony \\
\hline 6 & Boswellia serrata & Salai & Burseraceae & Stem & Marriage Ceremony \\
\hline 7 & Butea monosperma & Palash & Papilionaceae & Branches and leaves & Marriage Ceremony \\
\hline 8 & Brassica compestris & Sarson & Brassicaceae & Grains & Bad effect of Soul \\
\hline 9 & Calotropis procera & Akwan & Asclepiadaceae & Flowers & Mahashivaratri/ Lord Shiva \\
\hline 10 & Cannabis sativa & Bhang, Ganja & Cannabinaceae & Young leaves & Mahashivaratri/ Lord Shiva \\
\hline 11 & Capsicum annum & Mirchi & Solanaceae & Fruits & Bad evils eye \\
\hline 12 & Cicer arietinum & Chana & Papilionaceae & Pulses of Gram & God Bajrangbali \\
\hline 13 & Citrus limon & Neebu & Rutaceae & Fruits & Navratri \\
\hline 14 & Clitoria ternatea & Aparajita & Papilionaceae & Whole plants & Many holy functions \\
\hline 15 & Cocus nucifera & Nariyal & Arecaceae & Fruits & Many holy functions \\
\hline 16 & Curcuma domestica & Haldi & Zingiveraceae & Turmeric powder & Marriage Ceremony \\
\hline 17 & Cynodon dactylon & Doob & Poaceae & Whole plants & Many holy functions \\
\hline 18 & Datura alba & Dhatura & Solanaceae & Flowers & Mahashivaratri/ Lord Shiva \\
\hline 19 & Emblica officinalis & Amla & Euphorbiaceae & Fruits & Ichchha Navmi \\
\hline 20 & Epipremnum aureum & Money plant & Araceae & Whole plants & $\begin{array}{l}\text { Many holy functions and } \\
\text { happiness }\end{array}$ \\
\hline 21 & Eugenia jabolana & Jamun & Myrtaceae & Branches and leaves & Marriage Ceremony \\
\hline 22 & Ficus religiosa & Peepal & Moraceae & Whole plants & Many holy functions \\
\hline 23 & Ficus benghalensis & Bargad & Moraceae & Whole plants & Many holy functions \\
\hline 24 & Ficus virens & Pakar & Moraceae & Whole plants & Many holy functions \\
\hline 25 & Gloriosa superba & Kaliyari & Liliaceae & Root & Many holy functions \\
\hline
\end{tabular}

Volume 4 Issue 12, December 2015 
International Journal of Science and Research (IJSR)

ISSN (Online): 2319-7064

Index Copernicus Value (2013): 6.14 | Impact Factor (2014): 5.611

\begin{tabular}{|c|c|c|c|c|c|}
\hline 26 & Hordeum vulgare & Jawa & Poaceae & Whole plants & Many holy functions \\
\hline 27 & Ipomoea batatas & Sakarkand & Convovulaceae & Tuberous roots & Ganesh Chaturthi \\
\hline 28 & Lannea coromandelica & Gunja & Anacardiaceae & Stem & Marriage Ceremony \\
\hline 29 & Lawsonia alba & Mehdi & Lythraceae & Leaves & Rakshabandhan \\
\hline 30 & Mangifera indica & Aam & Anacardiaceae & Leaves & Marriage Ceremony \\
\hline 31 & Madhuca indica & Mahua & Sapotaceae & Flowers & Harchhath \\
\hline 32 & Mitragyna parviflora & Kaima & Rubiaceae & Whole plant & Many holy functions \\
\hline 33 & Musa paradisiaca & Kela & Musaceae & Leaves & Ganesh Chaturthi. \\
\hline 34 & Nelumbo nucifera & Kamal & Nymphaeaceae & Flower & Dipawali \\
\hline 35 & Nyctanthes arbortristis & Harsringar & Nyctaginaceae & Whole plant & Many holy functions \\
\hline 36 & Ocimum basilicum & Bobai & Lamiaceae & Whole plant & Many holy functions \\
\hline 37 & Ocimum sanctum & Tulsi & Lamiaceae & Whole plant & Many holy functions \\
\hline 38 & Oryza sativa & Dhan & Poaceae & Grains of Rice & Rakshabandhan and Khujliya \\
\hline 39 & Phoenix sylvestris & Khajur & Arecaceae & Leaves & Marriage Ceremony \\
\hline 40 & Piper betle & Pan & Piperaceae & Leaves & Many holy functions \\
\hline 41 & Polyalthia longifolia & Ashok & Annonaceae & Whole plant & Many holy functions \\
\hline 42 & Putranjiva roxburghii & Putranjiva & Euphorbiaceae & Whole plant & Many holy functions \\
\hline 43 & Sacchrum offcinarum & Ganna & Poaceae & Whole plant & Dipawali \\
\hline 44 & Sacchrum spontaneum & Kans & Poaceae & Whole plant & Harchhath \\
\hline 45 & Santalum album & Chandan & Santalaceae & Whole plant & Many holy functions \\
\hline 46 & Sesamum indicum & Tili & Pedaliaceae & Grains & Makarsankranti \\
\hline 47 & Tamarix ericoides & Jhau & Tamaricaeae & Stem & Many holy functions \\
\hline 48 & Trapa bispinosa & Singhara & Trapaceae & Fruits powder & Many holy functions \\
\hline 49 & Triticum aestivum & Gehu & Poaceae & Grains of Wheat & Addra Nakshtra \\
\hline 50 & Vigna mungo & Urda & Papilionaceae & Seeds & Many holy functions \\
\hline 51 & Ziziphus nummularia & Ber & Rhamnaceae & Whole plant & Harchhath \\
\hline
\end{tabular}

\section{References}

[1] Ahirwar, R.K., Diversity of Ethnomedicinal Plants in Boridand Forest of District Korea, Chhattisgarh, India. American Journal of Plant Sciences, 2015, 6, 413-425. http://dx.doi.org/10.4236/ajps.2015.62047

[2] Ahirwar, J.R. Socio-Religious Importance of plants in Bundelkhand Region of India. Res. J. Recent. Sci. 2013, 2: $1-4$

[3] Ahirwar, R.K., Ethnomedicinal uses of plant roots from Shadol district of M.P. India. Ind. J.Appl. Pure Bio. 2010, 25 (1) 71-76.
[4] Ahirwar,R.K. and Singh,G.K., Some anti diabetic plants from Dindori District of Madhya Pradesh (India). Ind. J.Appl. pure Bio. 2011, 26 (2) 269-271.

[5] Ahirwar, R.K., "Indian Folk Medicinal Plants of District Mandla Madhya Pradesh"LAP LAMBERT Academic Publishing GmbH \& Co. KG, Heinrich-Bocking-Str. 68,66121Saarbrucken, Germany. 2015, ISBN: 978-3659-42534-9

[6] Brijlal and Dube, V.P., A survey of the plant of ethnomedicine of Amarkantak Plateau in Central India. Agri. Biol. Res. 1992, 8(1):29-37.

[7] Gupta, A.K., Mishra, S.K. and Khan, A.A., Ethnobotanical notes on some herbs from Chhatisgarh

\section{Volume 4 Issue 12, December 2015}


region of Madhya pradesh. Ad. Plant Sci. 1999, 12 (1): 163-166.

[8] Gupta, Ashok Kumar and Mishra, S.K., Folklore dental protector plants of Chhatisgarh, India. Ad. Plant Sci., 2000, 13(11): 501-503.

[9] Jain, S.K., Medicinal plant lore of the tribals of Bastar. Econ. Bot. 1965, 19: 230-250.

[10] Jain, S.K. and Rao, R.R., A Handbook of Field and Herbarium methods. Today and tomorrow's Printers and Publishers. New Delhi, India. 1976.

[11]Khan, A.A., Agnihotri, S.K., Singh, M.K., and Ahirwar,R.K., Enumeration of certain angiospermic plants used by Baiga tribe for conservation of plant species. Plant archives, 2008, 8(1): 289-291.

[12] Khanna, K.K.; Kumar, A., Dixit, R.D. and Singh, N.P., Supplement to the Flora of Madhya Pradesh. Botanical Survey of India, Calcutta. 2001.

[13] Kumar, V. and Sikarwar, R.L.S., Observations on some rare and endangered plants of Chhattisgarh state, India. Phytotaxonomy 2002, 2: 135-142.

[14] Maheshwari, J.K., Recent ethnobotanical researches in Madhya Pradesh, S.E.B.S. News latter. 1990, 9(1-3) : 5.

[15] Oommachan, M. and Masih, S.K., Ethnobotanical observation on certain plants of the tribal region of M.P. Biome, 1993, 6(1): 59-64.

[16] Oommachan, M.; Shrivastava, J.L. and Shukla, Hemdutt, Observations on certain plants used in human skin diseases in Central India. Indian J. Applied \& Pure Biol. 1986, 1(1): 23-27.

[17] Panigarhi, G. and Murti, S.K., Flora of Bilaspur Vol. I. Botanical Survey of India, Calcutta. 1989.

[18] Sahu, T.R., Less known uses of weeds as medicinal plants. Ancient Science of Life, 1983, 4: 245- 249.

[19] Sharma, B.D., Balakrishnan, N.P., Rao, R.R. and Hajara, P.K. (eds.) Flora of India. Botanical Survey of India, Calcutta. 1993.

[20] Shukla, K.M.L., Khan, A.A., Khan, Shabina and Verma, Ashok Kumar, Ethnobotanical studies in Korba basin district Bilaspur (M.P.) India Ad. Plant Sci., 2001, 14(11): 391-394.

[21] Singh, N.P.; Singh, D.K.; Hajra, P.K. and Sharma, B.D. (eds.), Flora of India. Introductory, Vol. II. Botanical Survey of India, Calcutta. 2000.

[22] Verma, P.; Khan, A.A. and Singh, K.K., Traditional Phytotherapy among the Baiga Tribe of Shahdol district of Madhya Pradesh, India. Ethnobotany. 1995, 7: 69-73. 